\title{
Maize Genetics and Breeding in the 20th Century
}


This page is intentionally left blank 


\section{Maize Genetics and Breeding in the 20th Century}

Editors

\section{Peter A. Peterson}

lowa State University

Ames, lowa

\section{Angelo Bianchi}

Istituto Sperimentale Cerealicoltura

Rome 
Published by

World Scientific Publishing Co. Pte. Ltd.

P O Box 128, Farrer Road, Singapore 912805

USA office: Suite 1B, 1060 Main Street, River Edge, NJ 07661

UK office: 57 Shelton Street, Covent Garden, London WC2H 9HE

\author{
Library of Congress Cataloging-in-Publication Data \\ Peterson, Peter A. \\ Maize genetics and breeding in the 20th century / Peter \\ A. Peterson, Angelo Bianchi. \\ p. $\mathrm{cm}$.
}

Includes bibliographical references and index.

ISBN 981022866X (alk. paper)

1. Corn -- Breeding. 2. Corn -- Genetics. 3. Corn -- Breeding -

- Research -- United States. 4. Corn -- Genetics -- Research -- United

States. 5. Plant breeders -- United States -- Biography. 6. Plant

geneticists -- United States -- Biography. I. Bianchi, Angelo.

II. Title.

SB191.M2P4175 1999

633.1'52--dc21

98-38059

CIP

\begin{abstract}
British Library Cataloguing-in-Publication Data
A catalogue record for this book is available from the British Library.

Copyright $\odot 1999$ by World Scientific Publishing Co. Pte. Ltd

All rights reserved. This book, or parts thereof, may not be reproduced in any form or by any means, electronic or mechanical, including photocopying, recording or any information storage and retrieval system now known or to be invented, without written permission from the Publisher.
\end{abstract}

For photocopying of material in this volume, please pay a copying fee through the Copyright Clearance Center, Inc., 222 Rosewood Drive, Danvers, MA 01923, USA. In this case permission to photocopy is not required from the publisher. 


\section{Preface}

Upon my arrival in Cold Spring Harbor in the fall of 1947 to join the Demerec carcinogen project, I (PAP) was introduced to a Drosophila project for which I had near zero acquaintance. But with the patient tutelage of Dr. M. Demerec and Dr. Bruce Wallace, I soon became familiar with the materials and quickly became adept at handling the Drosophila cultures and finding mutants. In fact it became quite routine, but with my lab colleagues, the interest was enlivened by discussions-especially so with the continual flow of national and international visitors to the Cold Spring Harbor laboratories which generated more interest. This was 1947, and the effort to understand the gene was quite simplistic in the light of the revelations that would come in six years.

But the study of genetics had many aspects in the several laboratories at Cold Spring Harbor. There were the MacDowell mouse studies along with the B. Kaufmann and the Demerec Drosophila laboratories. In addition, both Demerec and E. Witkin had bacterial laboratories on locus dissection and repair enzymes.

But the plant genetic studies carried on in the small nursery next to the Carnegie library and the small watery inlet of the Harbor appeared to be more appealing. Of course, one could not separate the methodology of the maize nursery from the enthusiasm displayed by Barbara McClintock.

In any case, when I decided to embark on formal genetic training, it was not difficult to choose the organism for genetic study. That it became maize genetics and remained so for one-half a century is a testament to a rightful decision in 1948 as Sally and I headed for Illinois to join M. M. Rhoades. Yet, during the following three decades, I did have an opportunity to try other areas (a bacterial laboratory with P2 phage in Sweden in 1968, followed by mitochondrial laboratories in Vienna and in Cambridge, England in 1972-1973, and then again in a bacterial laboratory with the IS2 phage in Freiburg, Germany in 1977). Yet, maize was always a magnet beckoning me back to the field nursery. 
When I began the editorship of MAYDICA for the Americas, I became acquainted with the maize community as I handled submitted papers and sought diverse reviewers for the various maize related papers. Then the editorial board, and especially Francesco Salamini, suggested we begin commemorating noted maize breeders and geneticists who have contributed to maize as a major breeding accomplishment and genetic tool. This has led to a collection of papers especially generated by the enthusiasm and interest of the students and colleagues of those commemorated. Without this very active interest, the collection would not have been possible.

Through all this editing and activity, I have maintained my teaching and research activity along with generating desired mutants with the collaboration with the Max Planck Institute in Cologne for nearly two decades.

But I find it important to note that this pursuit in maize genetics and related activities would never have been possible without the supporting understanding of my wife, Sally. Only someone in research or especially in a maize program with the seven-day-week summers could appreciate the support that wives provide in their spouse's academic programs. For over half a century, Sally has not only supported but has provided an understanding ear to the ever-evolving developments that accompany an academic life. All the wives that have patiently sustained such a program deserve a sincere vote of thanks.

Peter A. Peterson Ames, Iowa 


\section{Acknowledgment}

Peter A. Peterson would like to acknowledge the dedicated effort by Ms. Wendy Henerlau in the attention and care that she has applied to the development of this book. 
This page is intentionally left blank 


\section{Contents}

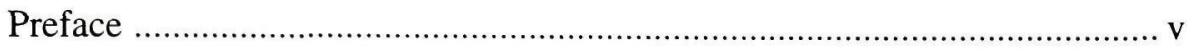

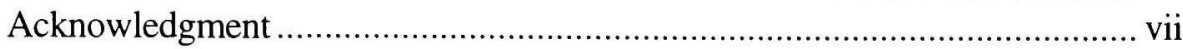

Part A Development of Maize Genetics and Breeding .................. 1

Peter A. Peterson

Introduction

Chapter 1 Flowering of Maize Genetics ................................................... 5

Chapter 2 Relevant Genetic Milestones in the Late 19th and

Early 20th Centuries ......................................................... 9

Chapter 3 The Maize Plant ................................................................... 13

Chapter 4 Emergence of Corn ................................................................ 15

Chapter 5 The Bussey Institute and Its Role in the Development

of Plant Science ............................................................ 17

Chapter 6 The Legendary School of Maize Genetics Under

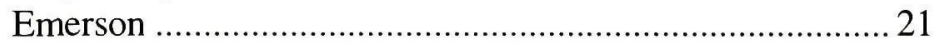

Chapter 7 The Early Maize Cytogenetics Group ………………………...2 25

Chapter 8 The Maize Breeding Group ...................................................... 43

Chapter 9 The Maize Evolution Group ………………………………...... 49

Chapter 10 A Later Genetics-Cytogenetics Group ......................................53

Chapter 11 Stock Center, Genetics, and Pathology ....................................5 59

Chapter 12 The Italian Maize Genetics Scientists ......................................... 63

Chapter 13 The Development of an Understanding of the Anthocyanin Pathway ........................................................ 65

Chapter 14 The Origin of the Allerton Maize Genetics Meetings ............... 69

Chapter 15 The Maize Community ……………………………………....... 77

Chapter 16 The Maize Pedigree Tree ………………………………....... 79

Chapter 17 Legacy of the Past …………………………...................... 83

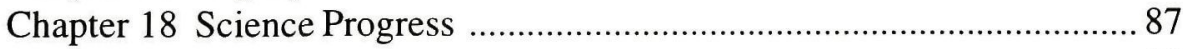

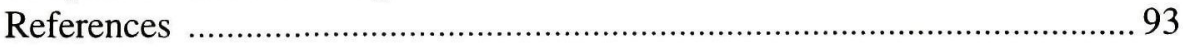

Part B The Commemorative Issues of MAYDICA …………..... 109

Chapter 19 William A. Russell .......................................................... 111

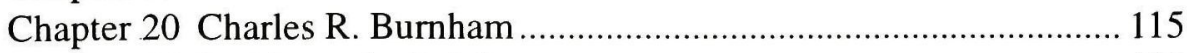

Chapter 21 R. Alexander Brink …………………………………….... 119 
Chapter 22 William L. Brown ........................................................... 127

Chapter 23 Marcus M. Rhoades ......................................................... 133

Chapter 24 George F. Sprague ........................................................... 143

Chapter 25 Paul C. Mangelsdorf .......................................................... 149

Chapter 26 Barbara McClintock ........................................................... 159

Chapter 27 Charles O. Gardner ........................................................ 163

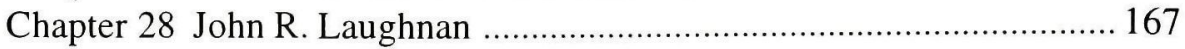

Chapter 29 Hugh H. Iltis ................................................................. 173

Chapter 30 Oliver E. Nelson, Jr. ...................................................... 179

Chapter 31 Drew Schwartz ................................................................ 185

Chapter 32 Peter A. Peterson ................................................................. 189

Chapter 33 Arnel R. Hallauer ............................................................. 201

Chapter 34 Earl B. Patterson ................................................................... 209

Chapter 35 Arthur Lee Hooker ................................................................ 217

Chapter 36 Myron G. Neuffer ............................................................... 223

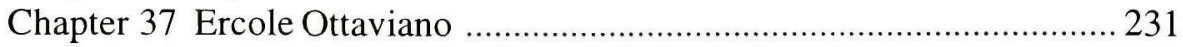

Chapter 38 Donald Sage Robertson ....................................................... 237

Chapter 39 Edward H. Coe, Jr.................................................................. 247

Chapter 40 Marcus S. Zuber ...................................................................... 251

Chapter 41 David B. Walden ................................................................. 269

Chapter 42 James D. Smith .................................................................. 277

\section{Part C Recent Developments in the Genetics and}

Molecular Biology of Maize Mutants ........................ 283

M. Motto, A. Bianchi and F. Salamini

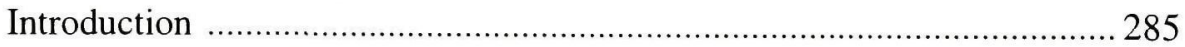

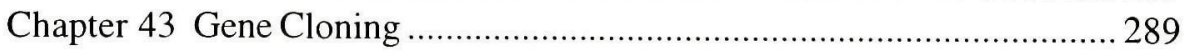

Chapter 44 Visiting the Genome ......................................................... 295

Chapter 45 Genome Dissection and Fingerprinting ................................ 303

Chapter 46 Biotechnology ..................................................................... 307

Chapter 47 Maize Development ............................................................. 317

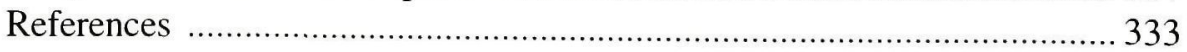

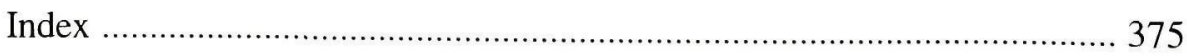

